\title{
Shozo Koguma: Studies on the Skin Colour of the Face of Healthy Adults
}

\section{正常人顔色についての研 究}

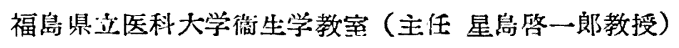

国馬 正 三

肌色の研究は現在多くの方面からその必要 が痛感されており，特に顔色による医学上の 診断や, 或いは又民族衛生学的方面でも肌色 の研究を果す割合は大きいものと考光られる。 教室の佐藤 1) 2) は反射光電比色計によつて肌 色の測定を行い，これを発表したが，肌には 肌特有の艶や，透明さがあつて，これ等を等 閑視出来ないことは勿論であり，佐藤の方法 ではこのためによる測定誤差は当然避け得な いものと思われる。而して著者は之等の因子 をも，いさ〉かでも表現しよ5として，塩化 ビニールを材料として作製された，日本色彩 研究所の肌色々票 3）を使用して, 顔の各部分, 即ち, 額, 煩, 蕦の夫々について測定し, そ の統計的結果を分解し, 更に各部位, 性则, 年令别及び，職業別等の条件による，数量的 関係を分析して得た結果を報告する。

\section{測定条件}

a. 対象：被験者は, 各種職業に彷事する各 年令層の健康男女 182 名(男 80 名, 女 102 名) であり，特に女性については，化粧を施さな い素顔を対象としたものである。

b. 測定場所,及び期間：大陽の直射する場 所をさけて, 晴天の日, 照度約 $500 \mathrm{Lux}$ の北 側の空際に於て測定し，期間は 1 月から, 5 月 迄の日中 (午前 10 時から, 午後 3 時迄の間) である。

c. 測定器具：日本色彩研究所の塩化ビニー ル製肌色々票を用いた。

d. 表示方法: 色研の「色の標準式記号」(色 相一明度一彩度) で表わし，数值は色の標準
の色標番号の外に，2色の間に属する色は, 目 測によりかなり細かく区分することが出来る ので, 数值を目測により 10 等分し 2 捨 3 入法 で 0.5 も表わした。

e. 測定者：著者及び正常眼の助手 1 名の測 定値の平均を最確値として取扱つた。二人の 比色值は有意の差が認められなかつた。

\section{測 定 成 績}

a. 対象の全体について：各要素の出現範囲 は, 色相 3.0 6.5, 明度 15.5 18.0, 彩度 $2.0 \sim$ 4.0 であつた。図 1〜3に示す如く, 全体につ いて性別による差は各要素共思つた程著明で なく，只極く僅かに女性の方が赤味を帯びて 明るいという印象を受けたのみであつたが， 夫々について $\chi^{2}$ 検定の 結果は次の通りであ つた。
1) 額 色相 $\chi^{2}=39.559 \quad 0.01>\mathbf{p}$
明度 $\chi^{2}=10.827 \quad 0.05>\mathrm{p}>0.02$
彩度 $\chi^{2}=4.027 \quad 0.5>\mathbf{p}>0.02$
2) 煩 色相 $\chi^{2}=40.142 \quad 0.01>\mathrm{p}$
明度 $\chi^{2}=11.274 \quad 0.05>\mathrm{p}>0.02$
彩度 $\quad \chi^{2}=8.849 \quad 0.1>\mathrm{p}>0.05$
3) 顎 色相 $\chi^{2}=32.4780 .01, \mathrm{p}$
明度 $\chi^{2}=5.7190 .3>\mathbf{p}>0.2$
彩度 $\chi^{2}=5.541 \quad 0.3>\mathrm{p}>0.2$

即ち, 各部分の色相のみ有意の差でもつて 男子の方が高值を示した。

b. 谷部位別について：額は色相が男子は比 較的黄味が〉つた傾向を示していたのに対し て，女子は各数值に平均して分布して扣り， 明度については, 女子の方が比較的高い数值 


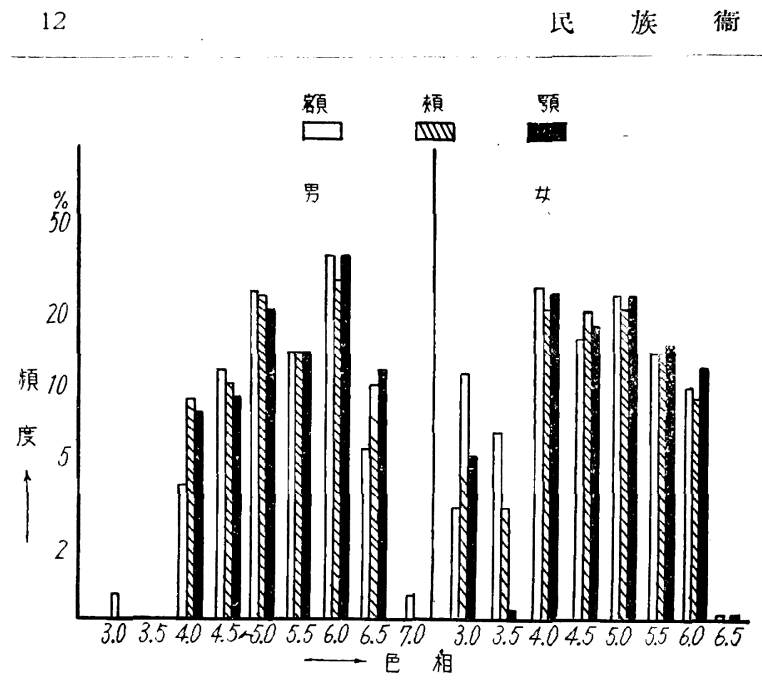

図1出現色相の分布

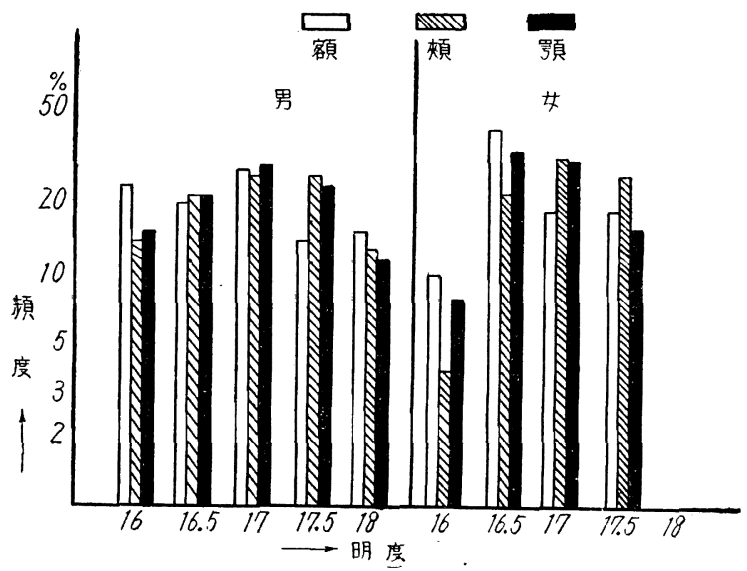

図 2 出圐明落の分布

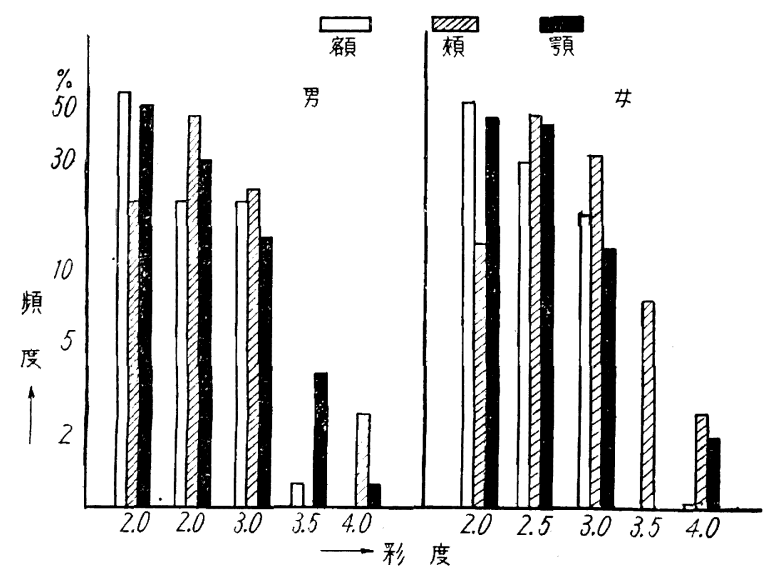

図 3 出垷彩度の分布
〔第 24 卷第 1 号

に分布していた。彩度は両方間に特に 著明な差は認められなかつた。煩は色 相, 明度, 彩度ともに差はなかつた。 顎については，色相，彩度は差わなか つたのであるが，常識的に額よりも暗 いと考光られて特り，日本色研の報告 3）にも暗いとされている明度汇於て， 著者の測定した限りでは, 明度 17.5 以 上のものが，額 61 名 $(33.5 \%)$ であつ たのに対して，顎が 75 名 (41.2\%) で 㐫り，顎の方が比較的明るいと云う印 象を受けたので，之に $\chi^{2}$ 検定を行つ て次の結果を得た。即ち $\chi^{2}=7.759$, $0.2>\mathrm{p}>0.1$ であつて有意の差はない と考えられた。

次に各部位の相関々倸を見るため に，相関々係数を算出して見をと次の 如くであつた。

1）額と頓

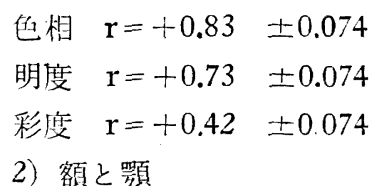

色相 $\mathrm{r}=+0.95 \pm 0.074$

明度 $r=+0.58 \pm 0.074$

彩度 $\mathrm{r}=+061 \pm 0.074$

3) 頓と顎

色相 $\mathrm{r}=+0.83 \pm 0.074$

明度 $\mathrm{r}=+0.60 \pm 0.074$

彩度 $\mathrm{r}=+0.51 \quad \pm 0.074$

以上の結果よりして，何れもが明ら か有意の正の相関を示した。

d. 年令別差異について：次に年令 別の差を見るべく，試みに39才以下 の者 142 名と, 40 才以上の者 40 名と に分けて，その各部分について $\chi$ 検 定を行つた。

1）額 色相 $\chi^{2}=39.287 \quad 0.01>p$ 明度 $\chi^{2}=18.299 \quad 0.01>p$ 
彩度 $\chi^{2}=7.769 \quad 0.2>\mathbf{p}>0.1$

2) 煩色相 $\chi^{2}=52.321 \quad 0.01>\mathrm{p}$

明度 $\chi^{2}=11.515 \quad 0.05>\mathrm{p}>0.02$

彩度 $\chi^{2}=7.614 \quad 0.2>\mathrm{p}>0.1$

3) 影 色相 $\chi^{2}=45.421 \quad 0.01>\mathrm{p}$

明度 $\chi^{2}=13.841 \quad 0.01>\mathrm{p}$

彩度 $\quad \chi 2=9.719 \quad 0.05>\mathrm{p}>0.02$

以上の結果より色相は有意の差でもつて高 年令者に高く, 額, 頸の明度では有意の差で

高年令者が低かつた。

彩度については谷部分ともに有意の差は認 められなかつた。

c. 性別について：全体としては前述の如 く，著差は認め難かつたのであるが，肌色は その生活形態炕より異ると常識的に考克ら秃 ているのでこえれを更に検討すべく，比較的観 察数が多く，乙かも大体同様な生活環境にあ ると考光られる。㟽家の男 32 名と，女 34 名 とについて比較して見たのであるが，額治色 相が男は 6.0 が最も多いのに対して，女は 4.5 が最も多く, 明度は男女共に 17.0 が最も多く, 彩度も男女共 2.0 が最も多かつた。頓の色相 は, 男が 5.5 と 6.0 が最も多く, 女は 4.5 が最 も多かつた。明度は男より女の方が高かつた。 彩度は特に著明な差は認め難かつた。顎につ いては，色相は男が 6.0 が最も多く，女は 4.5 が一番多かつた。明度は男が 16.0 ，女は 17.0 が最も多く, 彩度は男女共 2.0 が一番多からた のであるが，この夫々について 文検定を行 つて次の結果を得た。

1) 額 色相 $\chi^{2}=9.139 \quad 0.2>\mathrm{p}>0.1$

明度 $\chi^{2}=8.413 \quad 0.1>\mathrm{p}>0.05$

彩度 $\chi^{2}=4.461 \quad 0.3>\mathrm{p}>0.2$

2) 頓 色相 $\quad \chi=11.589 \quad 0.2>\mathrm{p}>0.1$

明度 $\chi^{2}=10.485 \quad 0.2>\mathbf{p}>0.1$

彩度 $\chi^{2}=2.431 \quad 0.7>\mathrm{p}>0.5$

3) 頡 色相 $\chi^{2}=7.642 \quad 0.2>p>0.3$

明度 $\chi^{2}=6.793 \quad 0.2>\mathrm{p}>0.1$

彩度 $\chi^{2}=6.552 \quad 0.2>\mathrm{p}>0.1$

即ち以上の結果より，何れも有意の差を持
たないと考えられた。

d. 職業別差異について：職業別の差を検討 与るため，代表として，主として屋外に於て 農耕に従事すると考光られる，農家の女 34 名 と，屋内勤務を主とする看護婦 15 名につい て，ての各要素について，各部分を比較して 見た。色相は，額，頼，顎共に農婦が高い值 の者が多く, 明度は, 各部位共に, 看護婦が 高い值を持つ者が多かつた。即ち看護婦の方 が，より赤味をおびて，明るい者が多からた わけである。彩度については，額と顎は，両 者共に 2.0 の者が最も多かつたが，煩は農婦が 2.5 , 看護婦は 2.0 と 3.0 の者が多かつた。更に その各部分について， $\chi^{2}$ 検定を行つて見た。

1）額 色相 $\chi^{2}=15.931 \quad 0.02>p>0.01$

明度 $\chi^{2}=11.599 \quad 0.05>\mathrm{p}>0.02$

彩度 $\chi^{2}=2.987 \quad 0.3>\mathrm{p}>0.2$

2) 煩 色相 $\chi^{2}=21.759 \quad 0.01>p$

明度 $\chi^{2}=10.201 \quad 0.05>\mathrm{p}>0.02$

彩度 $\quad \chi^{2}=12.308 \quad 0.02>\mathrm{p}>0.01$

3) 買 色相 $\chi^{2}=22.343 \quad 0.01>\mathrm{p}$

明度 $\chi^{2}=9.921 \quad 005>\mathrm{p}>0.02$

彩度 $\chi^{2}=4.224 \quad 0.3>\mathrm{p}>0.2$

以上の結果よりして，頉と顎の色相のみ有 意の差で看護婦が低かつた。

\section{総括並びに結論}

日本色彩研究所の塩化ビニール製肌色々票 を用いて，健康男女 182 名の顔の各部分，額， 煩, 歌について澒定し, 之の性別の差, 各部 位の相関，年令別の差，更に職業別の差につ いて，検討を試みたのであるが，穴の結果と して

a) 性別については, 男女の差は思つ程多く わなく，女性の方が極く僅かに，赫味を蒂び て明るいという印象を受けたのみであつたが， 义 2 検定の結果は，各部位の色相にの及有意の 差で男子の方が高値を示した。更に農家の男 女については，その各部位，各要素共に有意 差わ認められなかつた。 
b) 各部位別の差については，特に著明な差 は認め難かつたが，各部位の各要素は夫々有 意の正の相関を示した。

c）年令別の差については，39才以下の者 と, 40 才以上の者について比較したのである が，各部位の色相は高年令者に高く, 額と顎 の明度では高年令者は有意の差で低かつた。 彩度については 各部位共に有意の差は認め られなかつた。

d）職業別の差を見るために，看護婦と農婦 を比較してみたが，看護婦の方がより赤味が かつているが，明るく，彩度は非常に高い者 と低い者があつたが，各部分について $\chi^{2}$ 検 定の結果，頓と顎の色相にのみ有意の差で看 護婦は低かつた。
以上の如くであつたが，更に例数を重ねて， 季節による変化等についても検討する予定で ある。

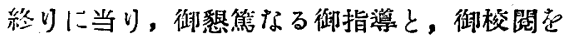
賜つた，星島管一郎教授並びに，調查に当り， 終始適切なる御指導

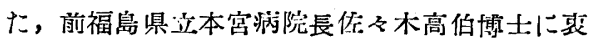
心より深謝致します。

\section{文献}

1) 佐藤健象：肌色, 味賞, 嗅覚, 第 26 回日本 衙生学総会 (全沢市), 1956.

2）佐藤健象：肌色，味賞，嗅覚，第 27 回日本 葓生学総会 (箱根), $195 \%$.

3）日本色彩研究所：技衍部報告, No. 20, 肌色 々曹研拀 (3)…(1), 1955, 3, 20. 


\section{Siudies on the Sensitivity of Taste and Taste-Blindness of Japanese. \\ II. The Reactions of the Taste of Identical Twins, and the Application of these Results to the \\ Diagnosis of Identity.}

\section{Takao FujINo}

The identity of a pair of twins, found in the data of his former studies on the senses of taste, had already been confirmed by the author, using several substances for deciding whether they are identical or dizygotic. Through his researches in the taste of these twins to be regarded as identical, the author has reached the following results, making use of the three reagents of P.T.C., lactose and aspirin.

1. Both of the twins tasted the bitterness of P.T.C. and even to the P.T.C. solution diluted ninety-thousand-fold they complained of equal bitterness.

2. To the lactose they had the sensation of bitterness, and to the aspirin they both seemed to have tasted something strange and told that it was rather astringent.

3. From these results of the entirely same taste reactions in the identical twins, the inheritable character of the sense of taste can be clearly inferred.

4. Thus the taste of taste reactions to some medical substances may be added to the hitherto known diagnostic methods for determining twins as identical or dizygotic.

(From the Department of Public Health, Fukushima Medical College, Fukushima)

Studies on the Skin Colour of the Face of Healthy Adults Shozo Koguma

The author has been engaging in the research on the skin colour of the face, using a colour scale. The colour table was specially made for the determination of the skin colour by Japan Colour Institute with polyvinyl plastic.

This paper is a record of the skin colour of the face observed in 80 male and 82 female who are all healthy adult Japanese. The results obtained are as follow:

1. Difference by sex: the difference between both sexes were not so distinct as expected, and only in hue, male showed the significantly higher value than famale.

2. Difference among forehead, cheek and chin: the significant correlations were observed in three elements-hue, luminesity, and saturation. 
3. Difference between the younger age group and the elder one: the author divided the persons tested into two age groups, i. e. the group of 39 years old or younger, and the group of 40 years old or elder. The values of hue in the three parts of the latter were higher than that of the former, and the values of luminosity of forehead and chin of the latter is significantly lower than that of the former.

4. Difference by occupations: the author compared the akin colour of nurses and that of women working on farm, and only found the significant difference in the hue of cheek and chin of them; i. e. that of the former was lower than that of the latter.

(From the Department of Hygiene, Fukushima Medical Colloge, Fukushima, Japan)

On the Methodology for the Epidemiological Study of Heart Disease

Toshio IsHIBASHI

Although the incidence of deaths resulting from heart disease in Japan is still considerably lower than the of some foreigh countries, a continuous rise in the numer of such deaths is discernible over recent years.

In order to determine the prevalence level and what factors are responsible for this trend, the need for systematic epidemiological studies is indicated. In carrying out such a project, careful methodological consideration should be given to the techniques suitable for the survey as well as to the time, place and person preferably to be selected for studies.

The results, using death statistics, $\mathrm{X}$-ray and electrocardiogramme as the indices of the studies, reported as follows:

1. Age: all three indices indicate that as age increases, the prevalence cf heart disease increases proportionally.

2. Sex: death statistics and E.C.G. show that a higher percentage of men suffer from heart discase, while X-ray reveal that the percentage of hypertrophy is higher in female than in male especially in rural district.

3. Urban \& rural relations: death statistics and X-ray show a higher prevalence of the disease in urban area, while E.C.G. indicate a higher percentage of prevalence in rural district. In the case of abnormal $\mathrm{P}$-wave and arythomia, however, the percentage is found higher in urban area than in rural district.

4. Diet: death statistics and E.C.G. indicate a higher prevalence among overweight-persons, though X-ray indicate a higher rate of hyphertrophy among underweight-persons.

5. Nationality: there is no marked difference in the percentage of abnorma- 